DOI: https://doi.org/10.24127/ajpm.v10i4.4193

\title{
PENGEMBANGAN LEMBAR KERJA PESERTA DIDIK BERBASIS DISCOVERY LEARNING PADA MATERI MATRIKS
}

\author{
Yerizon $^{1^{*}}$, Lialy Sarti $^{2}$ \\ ${ }^{1 * 2}$ Universitas Negeri Padang, Fakultas Matematika dan Ilmu Pengetahuan Alam, \\ Universitas Negeri Padang, Indonesia \\ *Corresponding author. Jl. Prof. Dr. Hamka Air Tawar Padang, Sumatera Barat, Indonesia

$$
\text { E-mail: yerizon@fmipa.unp.ac.id }{ }^{* *}
$$$$
{\text { lialysarti1710@ } \text { gmail.com }^{2}}^{2}
$$

Received 03 September 2021; Received in revised form 17 November 2021; Accepted 28 December 2021

\begin{abstract}
Abstrak
Tujuan dari penelitian ini adalah mengembangkan LKPD dengan materi matriks yang valid dan praktis berbasis model pembelajaran discovery learning. Penelitian ini adalah penelitian pengembangan model Plomp yang terdiri atas tiga fase yaitu preliminary research (fase investigasi awal), development or prototyping phase (fase pengembangan atau pembuatan prototype), dan assessment phase (fase penilaian). Instrumen yang digunakan adalah angket, pedoman wawancara, dan lembar observasi. Data hasil angket dianalisis denganStatistic deskriptif, sedangkan data hasil observasi dan wawancara dianalisis denganteknik deskriptif. Hasil penelitian diperoleh bahwa LKPD dikatakan valid dengan nilai validitas sebesar 82,78\% dengan kategori sangat valid, 2) LKPD dikatakan praktis, karena dapat digunakan dengan mudah oleh peserta didik dalam proses pembelajaran dengan nilai praktikalitas sebesar $88,47 \%$ dengan kategori sangat praktis. Berdasarkan hasil penelitian dapat disimpulkan bahwa LKPD yang dihasilkan dapat digunakan dalam pembelajaran matematika di sekolah.
\end{abstract}

Kata kunci: Discovery learning; matriks; model Plomp; LKPD.

\begin{abstract}
The purpose of this research is to develop student worksheets on the matrix that is valid and practical using the discovery learning model. This is because the student worksheets used in the learning process are still not able to facilitate students to be actively involved in discovering a concept or principle to construct their knowledge. The type of this research is Research and Development (R\&D). This research used the Plomp model which consists of three phases, namely preliminary research, development or prototyping phase, and assessment phase. The research data were collected by using a questionnaire, interview, and observation. The data from the questionnaire were analyzed by using descriptive techniques, while the data from observations and interviews were analyzed by using descriptive statistics. The results of this research are (1) the student worksheets developed has a very valid category with a validity value of $82.78 \%$, (2) the student worksheets can be used easily by students in the learning process with a practicality value of $88.47 \%$ with very practical category. Based on the research results, it can be concluded that the developed student worksheets can be applied in mathematics learning in schools.
\end{abstract}

Keywords: Discovery learning; matrix; Plomp model; student worksheet.

Thisis an open access article under the Creative Commons Attribution 4.0 International License

\section{PENDAHULUAN}

Perkembangan IPTEK pada abad 21 menuntut manusia untuk mempunyai terobosan pemikiran untuk mampu bersaing dalam dunia kerja dan menciptakan karya yang monumental. (Wijaya et al., 2016) mengungkapkan banyak pekerjaan yang sifatnya rutin sudah digantikan oleh komputer. Untuk itu, pakar pendidikan harus memikirkan 
cara membekali peserta didik supaya siap menghadapi tantangan tersebut.

Matematika adalah ilmu yang menjadi pondasi bagi pengembangan ilmu pengetahuan dan teknologi. Semua bidang ilmu memerlukan matematika untuk meningkatkan keluasan dari ilmu tersebut. Dengan adanya matematika maka ilmu tersebut mudah untuk dikembangkan. Untuk itu, perlu diajarkan matematika di sekolah berdasarkan Permendikbud Nomor 59 Tahun 2014 mengenai Kurikulum 2013 SMA/MA. Belajar matematika bertujuan untuk memahami konsep matematika, mengembangkan kemampuan komunikasi matematis, kemampuan penalaran, kemampuan pemecahan masalah, sikap menghargai matematika, serta memiliki perilaku sesuai dengan nilai matematika.

Pembelajaran pada kurikulum 2013 menuntut peserta didik menggali sendiri konsep yang dipelajari. Guru hanya berperan sebagai fasilitator dalam proses pembelajaran. Maka dari itu, guru dituntut untuk kreatif dalam merencanakan kegiatan belajar yang membuat peserta didik terlibat aktif. Dalam merencanakan pembelajaran tentunya sangat dibutuhkan bahan ajar yang baik agar tujuan pembelajaran tercapai. Bahan ajar yang digunakan sebaiknya menuntun peserta didik untuk mencapai kemampuan yang diinginkan (Nurhikmayati \& Jatisunda, 2019), (Andriyani \& Saputra, 2020). Guru perlu membuat Rencana Pelaksanaan Pembelajaran (RPP), silabus, media dan sumber belajar, perangkat penilaian pembelajaran, dan skenario pembelajaran (Kemendikbud, 2016).

Sumber belajar yang digunakan saat ini adalah buku paket matematika dan LKPD, namun keduanya bukan dirancang oleh guru. Bahan ajar khususnya LKPD yang tersedia belum menyediakan kegiatan yang menuntun peserta didik dalam menemukan suatu konsep. Akibatnya siswa tidak dapat memahami materi dengan baik, seperti hasil ujian topik matriks pada Tabel 1 .

Tabel 1. Nilai penilaian harian peserta didik pada materi matriks

\begin{tabular}{lcc}
\hline Kelas & \multicolumn{2}{c}{ Ketuntasan Belajar Minimum (\%) } \\
\cline { 2 - 3 } Tidak Tuntas & Tuntas \\
\hline XI IPA 1 & 34,23 & 65,77 \\
XI IPA 2 & 31,43 & 68,57 \\
XI IPA 3 & 28,57 & 71,43 \\
XI IPA 4 & 45,45 & 54,55 \\
XI IPA 5 & 47,22 & 52,78 \\
XI IPA 7 & 58,33 & 41,67 \\
XI IPA 8 & 50,00 & 50,00 \\
\hline
\end{tabular}

Berdasarkan Tabel 1, terlihat bahwa peserta didik mengalami kesulitan pada materi matriks. Selain itu, peserta didik selalu menunggu penjelasan dari guru sehingga dapat dikatakan tidak mandiri dalam belajar. Materi pada LKPD disajikan secara ringkas dan tidak menyajikan cara memperoleh rumus yang dipelajari sehingga sulit dipahami. Tidak ada langkah-langkah yang membimbing peserta didik dalam proses penemuan konsep secara bermakna. Peserta didik hanya dituntut untuk mengerjakan soalsoal pada LKPD. Hal ini tidak sesuai dengan prinsip penggunaan LKPD, yaitu sebagai bahan ajar yang berisi petunjuk untuk menemukan suatu konsep (Pansa et al., 2017), (Hendri \& Kenedi, 2018), (Septian et al., 2019).

Oleh karena itu, perlu dikembangkan LKPD yang sesuai dengan karakteristik peserta didik dan memfasilitasi dalam menemukan konsep atau prinsip guna mengkonstruksi pengetahuan tentang matriks. LKPD merupakan sarana pembelajaran yang digunakan untuk meningkatkan keterlibatan peserta didik dalam proses pembelajaran (Zulfah, 2017), (Apertha et al., 2018), (Noprinda \& Soleh, 2019). 
DOI: https://doi.org/10.24127/ajpm.v10i4.4193

Model pembelajaran yang dapat membantu peserta didik dalam menemukan suatu konsep melalui proses mentalnya adalah model discovery learning (Haeruman et al., 2017), (Yerizon et al., 2018), (Fitriyana \& Purwasi, 2020). Pada pembelajaran discovery learning, peserta didik dituntut untuk terlibat secara aktif dalam menemukan sendiri konsep atau prinsip. Hasil penelitian sebelumnya menunjukkan bahwa model discovery learning dapat meningkatkan pemahaman konsep matematis (Romadon \& Mahmudi, 2019), kemampuan penalaran (Fadli \& Mirna, 2019), (Meiliputri et al., 2021), kemampuan komunikasi matematis (Arifin \& Abadi, 2018), dan kemampuan pemecahan masalah matematis peserta didik (Hakim \& Noer, 2021).

Model discovery learning memiliki 6 tahapan, yaitu Stimulation, Problem Statement, Data Collection, Data Processing, Verification, dan Generalization. Pada tahap Stimulation, peserta didik diberikan sesuatu yang dapat merangsang rasa ingin tahu peserta didik untuk menyelesaikan atau menyelidiki sendiri. Pada tahap Problem Statement, peserta didik diberi kegiatan untuk mengidentifikasi masalah yang diberikan. Kemudian merumuskan jawaban sementara atas pertanyaan masalah (hipotesis).

Pada tahap Data Collection, peserta didik mengumpulkan berbagai keterangan untuk membuktikan benar atau tidaknya hipotesis yang telah dirumuskan. Hal ini dapat dilakukan dengan cara membaca berbagai sumber, observasi objek, wawancara, melakukan percobaan sendiri, dan sebagainya. Tahapan ini bertujuan membuat peserta didik aktif untuk menghasilkan sesuatu yang terkait dengan persoalan yang dihadapi. Tahap Data Processing, peserta didik mengolah data dan informasi yang diperoleh kemudian mengklasifikasikan dan menafsirkan data. Tujuannya untuk pembentukan konsep dan generalisasi.

Pada tahap Verification, peserta didik memeriksa dengan cermat tentang pembuktian benar atau tidaknya hipotesis yang telah dirumuskan dengan alternatif jawaban. Pada tahap Generalization, peserta didik menarik kesimpulan yang menjadi prinsip umum dan dapat digunakan untuk masalah serupa dengan berpedoman kepada hasil verifikasi yang telah dilakukan.

Pada penelitian di atas belum ada penelitian pengembangan LKPD pada topik matriks. Pada umumnya adalah penelitian eksperimen dengan topik matematika yang lain. Padahal topik matriks masih menjadi masalah bagi peserta didik. Berdasarkan masalah yang telah dipaparkan, tujuan dari penelitian ini adalah untuk mengembangkan LKPD berbasis discovery learning pada topik matriks yang valid dan praktis.

\section{METODE PENELITIAN}

Penelitian ini merupakan penelitian pengembangan model Plomp yang memiliki tiga fase yaitu preliminary research, development or prototyping phase, dan assessment phase (Plomp \& Nieveen, 2013) pada materi matriks. Namun, karena Covid 19 maka terdapat beberapa penyesuaian dimana uji coba produk hanya sampai uji praktikalitas pada evaluasi kelompok kecil.

Pada preliminary research dilakukan analisis kebutuhan, analisis kurikulum, analisis konsep, dan analisis peserta didik. Hasil pada fase ini merupakan informasi yang dibutuhkan dalam pembuatan prototipe. Hasil rancangan ini dievaluasi sendiri dan 
disebut prototipe 1. Kemudian, prototipe 1 divalidasi oleh para ahli. Penentuan nilai hasil validasi dilakukan dengan menggunakan rumus yang dikemukakan sebagai berikut:

$$
R=\frac{\sum_{j=1}^{m} \overline{x_{j}}}{m}
$$

Keterangan:

$$
\begin{array}{lll}
R: & \text { Validitas perangkat } \\
& \text { pembelajaran } \\
\bar{x}_{j}: & \text { Rerata hasil penilaian validitas } \\
& \text { item ke-j } \\
m: & \text { Banyak item }
\end{array}
$$

Interpretasi validitas perangkat pembelajaran ditentukan dengan kriteria seperti yang ditampilkan pada Tabel 2.

Tabel 2. Kriteria validitas LKPD

\begin{tabular}{cc}
\hline Kriteria & Interpretasi \\
\hline $\mathrm{R} \leq 0,08$ & Tidak valid \\
$0,08<\mathrm{R} \leq 1,60$ & Kurang valid \\
$1,60<\mathrm{R} \leq 2,40$ & Cukup valid \\
$2,40<\mathrm{R} \leq 3,20$ & Valid \\
$\mathrm{R}>3,20$ & Sangat valid \\
\hline
\end{tabular}

Sumber: (Irwan et al., 2018)

Setelah divalidasi LKPD yang telah valid disebut prototipe 2 . Selanjutnya, prototipe 2 diujicobakan kepada tiga orang peserta didik pada tahap evaluasi perorangan. Tahap ini bertujuan untuk mengetahui kemungkinan kesalahan (error) pada LKPD yang telah dikembangkan dengan instrumen berupa lembar observasi dan pedoman wawancara. LKPD yang telah direvisi kemudian disebut prototipe 3 .

Prototipe 3 diujicobakan kepada enam orang peserta didik untuk mengetahui praktikalitas LKPD pada tahap evaluasi kelompok kecil. Instrumen yang digunakan pada tahap evaluasi kelompok kecil adalah pedoman wawancara dan angket uji praktikalitas.

Penentuan nilai praktikalitas produk dilakukan dengan menggunakan rumus berikut:

$$
P=\frac{R}{S M} \times 100 \%
$$

Keterangan:

$P$ : Nilai praktikalitas

$R$ : Jumlah skor semua item

$S M$ : Jumlah skor maksimal

Kategori praktikalitas ditentukan dengan kriteria seperti yang disajikan pada Tabel 3.

Tabel 3. Kategori kepraktisan LKPD

\begin{tabular}{ccl}
\hline No & $\begin{array}{c}\text { Tingkat } \\
\text { Pencapaian }(\%)\end{array}$ & \multicolumn{1}{c}{ Kategori } \\
\hline 1 & $85-100$ & Sangat Praktis \\
2 & $75-84,9$ & Praktis \\
3 & $60-74,9$ & Cukup Praktis \\
4 & $55-59,9$ & Kurang Praktis \\
5 & $0-54,9$ & Tidak Praktis \\
\hline Sumber: (Rosmaiyadi, 2017)
\end{tabular}

\section{HASIL DAN PEMBAHASAN}

\section{A. Hasil Penelitian}

\section{Hasil Preliminary Research}

Berdasarkan penelitian pendahuluan diperoleh bahwa LKPD dengan model discovery learning ini memang sangat dibutuhkan. LKPD yang ada belum membantu peserta didik belajar secara maksimal. Dari kurikulum yang digunakan diperoleh bahwa telah dirumuskan indikator dari tiap topik ini.

Berdasarkan analisis konsep diperoleh materi utama mengenai matriks yang akan dipelajari oleh peserta didik. Hasil analisis konsep dapat dilihat pada Gambar 1. 
DOI: https://doi.org/10.24127/ajpm.v10i4.4193

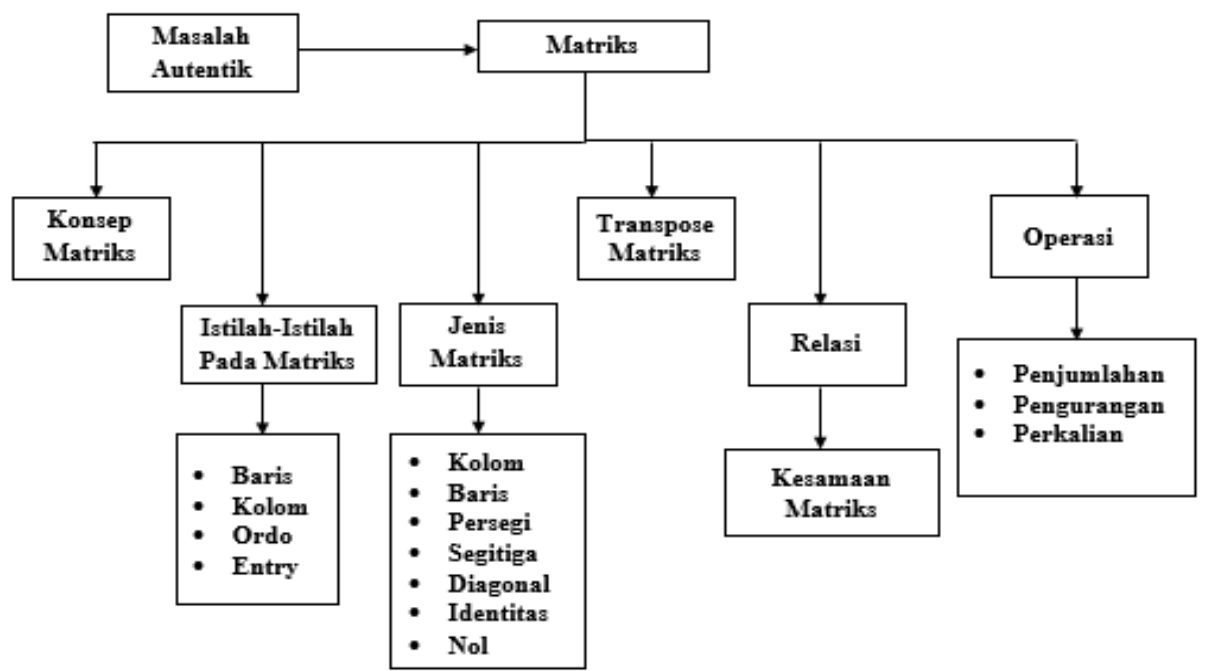

Gambar 1. Peta konsep materi matriks

$\begin{array}{llr}\text { Karakteristik } & \text { peserta } & \text { didik } \\ \text { diperoleh dengan observasi } & \text { dan } \\ \text { wawancara. Beberapa temuan } & \text { yang }\end{array}$ diperoleh yaitu (1) peserta didik akan bertanya kepada guru atau teman jika tidak paham; (2) peserta didik suka belajar secara berkelompok dan merasa puas ketika mempresentasikan hasil diskusi yang diperoleh; (3) peserta didik memerlukan bahan ajar yang lengkap dan ada penjabaran untuk memperoleh rumus serta contoh soal yang banyak; (4) peserta didik menyukai LKPD dengan warna dan gambar yang bervariasi dan menarik, bahasanya mudah dipahami, dan tulisannya dapat dibaca dengan jelas; (5) peserta didik menyukai warna biru untuk menjadi warna dominan pada LKPD; (6) peserta didik menyukai tulisan Times New Roman dengan ukuran 12 serta ukuran kertas LKPD yang digunakan adalah A4; (7) peserta didik tinggal di lingkungan pedesaan yang mayoritas mata pencaharian masyarakatnya adalah bertani atau berkebun.

\section{Hasil Prototyping Phase}

Berdasarkan hasil Preliminary Research maka dirancanglah LKPD berbasis discovery learning untuk topikmatriks. Kegiatan pembelajaran sesuai dengan langkah-langkah model discovery learning, serta soal latihan. Hasil ini disebut prototipe 1. Setelah itu dilakukan validasi oleh para pakar, hasilnya dapat dilihat pada Tabel 4 .

Tabel 4. Hasil Validasi LKPD

\begin{tabular}{lcl}
\hline \multicolumn{1}{c}{ Aspek } & $\begin{array}{c}\text { Validitas } \\
(\mathbf{\%})\end{array}$ & \multicolumn{1}{c}{ Kategori } \\
\hline Penyajian & 82,00 & Sangat Valid \\
Kelayakan Isi & 84,52 & Sangat Valid \\
Kebahasaan & 81,25 & Sangat Valid \\
Kegrafikaan & 83,30 & Sangat Valid \\
\hline Rata-rata & $\mathbf{8 2 , 7 8}$ & Sangat Valid \\
\hline
\end{tabular}

Rata-rata nilai validitas oleh pakar adalah $82,78 \%$ dengan kategori sangat valid. Hasil ini disebut prototipe 2 . Selanjutnya, prototipe 2 diujicobakan pada tahap one-to-one kepada tiga orang peserta didik dengan tingkat kemampuan berbeda. Beberapa perbaikan yang dilakukan adalah perbaikan pada petunjuk soal, perbaikan pada kalimat perintah, penambahan informasi atau petunjuk, dan kesalahan dalam pengetikan.

Berdasarkan hasil pengamatan terhadap peserta didik saat mengerjakan LKPD pertemuan 1, terlihat bahwa peserta didik dapat mengerjakan 
aktivitas-aktivitas pada LKPD dengan baik, walaupun masih banyak arahan dari guru. Peserta didik belum terbiasa dalam mengerjakan LKPD yang menuntut peserta didik berpikir dalam menemukan sendiri serta peserta didik masih belum terbiasa mengerjakan masalah kontekstual.

Contoh jawaban peserta didik berkemampuan rendah setelah diberikan arahan dalam menggeneralisasi notasi umum dari ordo matriks dan entry matriks dapat dilihat pada Gambar 2.

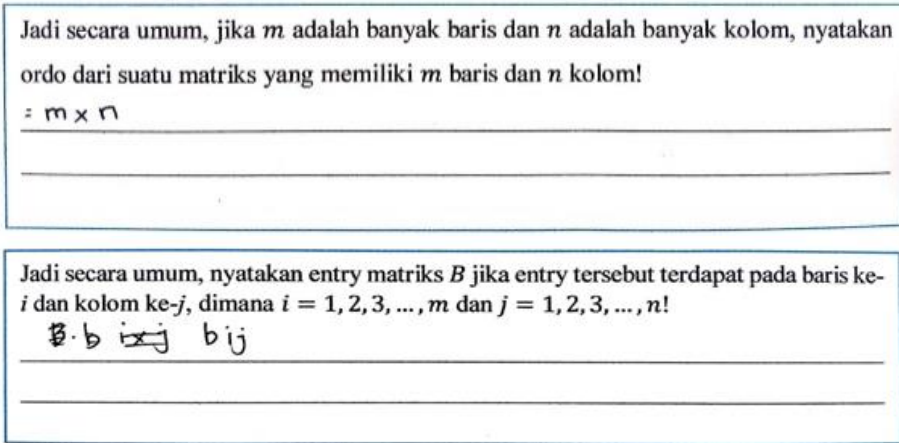

Gambar 2. Contoh jawaban peserta didik

Pada pertemuan 2, peserta didik mulai terbiasa dalam mengerjakan LKPD. Dalam mengerjakan LKPD, hanya sedikit peserta didik yang bertanya kepada guru. Pada pertemuan 2 ini, peserta didik dapat memahami stimulus yang diberikan. Kesulitan peserta didik yang tampak pada pertemuan 2 ini adalah pada kegiatan generalization dimana peserta didik diminta untuk menyimpulkan cara menentukan transpose matriks. Selain itu, peserta didik awalnya hanya memberikan satu alasan mengapa dua matriks tersebut sama. Setelah guru mengganti kalimat pertanyaannya, peserta didik dapat menjawab dua alasan tersebut dengan tepat.

Pada pertemuan 3 ini, peserta didik kesulitan dalam menuliskan hubungan antara matriks $\mathrm{C}$ dengan matriks A dan B, walaupun peserta didik megetahui bahwa hubungannya adalah matriks $\mathrm{C}$ merupakan hasil penjumlahan matriks A dan B. Pada pertemuan 4, peserta didik dapat mengerjakan LKPD tanpa bertanya kepada guru. Peserta didik dapat mengerjakan LKPD lebih baik daripada pertemuan sebelumnya. Peserta didik juga tidak ada yang mengalami kesulitan pada pertemuan 4 ini.

Pada pertemuan 5, peserta didik sering mengalami kesulitan. Oleh karena itu, guru cukup sering memberikan arahan kepada peserta didik. Kesulitan peserta didik yang tampak adalah pada kegiatan generalization dimana peserta didik diminta untuk menyimpulkan cara melakukan perkalian skalar pada matriks dan perkalian dua matriks serta pada saat mengalikan matriks A terhadap matriks B. Setelah diberikan arahan, peserta didik dapat menyimpulkan dan menyelesaikan operasi perkalian tersebut dengan tepat.

Berdasarkan hasil wawancara diperoleh kesimpulan yaitu (1) kejelasan petunjuk dan tulisan; (2) bahasa mudah dipahami; (3) LKPD dapat membantu mengkonstruksi konsep; (4) waktu yang digunakan sesuai.

Hasil yang diperoleh dinamakan prototipe 3. Prototipe 3 kemudian diujicobakan kepada enam orang 
peserta didik pada evaluasi kelompok kecil yang terdiri dari masing-masing dua orang berkemampuan rendah, sedang, dan dua tinggi. Kemudian, enam orang peserta didik tersebut dibagi menjadi dua kelompok yaitu dengan kemampuan berbeda.

Kegiatan evaluasi kelompok kecil dilaksanakan sebanyak 5 pertemuan. Kegiatan pembelajaran menggunakan model Discovery Learning. Kegiatan pendahuluan dimulai dengan berdo'a. Salah seorang peserta didik diminta untuk memimpin do'a. Setelah berdo'a, guru menginformasikan kepada peserta didik bahwa pembelajaran akan dilaksanakan secara berkelompok. Setelah membagi kelompok, guru memberikan apersepsi mengenai sistem persamaan linear yang telah dipelajari sebelumnya. Setelah itu, guru menyampaikan tujuan pembelajaran, cakupan materi dan motivasi. Kemudian, guru menyampaikan kepada peserta didik untuk memahami petunjuk pada LKPD.

Berdasarkan hasil pengamatan terhadap peserta didik saat mengerjakan LKPD pertemuan 1, terlihat bahwa kegiatan pembelajaran dapat terlaksana dengan baik walaupun masih ada arahan dari guru. Peserta didik masih belum terbiasa dalam mengerjakan LKPD. Akan tetapi, peserta didik tertarik dan bersemangat dalam belajar. Alokasi waktu pada pertemuan 1 ini juga cukup efisien untuk melaksanakan kegiatan pada LKPD. Peserta didik dapat menjawab pertanyaan dengan baik walaupun terkadang mengalami kesulitan. Kesulitan yang dialami peserta didik yaitu pada kegiatan problem statement dan generalization. Setelah diberikan arahan, peserta didik akhirnya dapat menjawab dengan tepat. Secara keseluruhan, peserta didik dapat memahami konsep matriks, ordo, entry, dan jenis-jenis matriks dengan baik.
Pada pertemuan 2, terlihat bahwa peserta didik sudah mulai terbiasa dengan LKPD. Peserta didik juga sudah sedikit yang bertanya kepada guru. Selain itu, peserta didik juga terlihat bersemangat dalam belajar. Kegiatan pembelajaran pada pertemuan 2 juga terlaksana dengan baik dan alokasi waktu efisien. Kesulitan peserta didik hanya tampak pada kegiatan generalization. Secara keseluruhan, peserta didik dapat memahami transpose dan kesamaan matriks dengan baik.

Pada pertemuan 3, terlihat bahwa peserta didik sudah terbiasa mengerjakan LKPD dengan mengikuti langkah-langkah yang diberikan. Bahkan, peserta didik lebih bersemangat dari pertemuan sebelumnya. Sama halnya dengan pertemuan 2 , pada pertemuan 3 ini peserta didik juga terlihat kebingungan pada kegiatan generalization. Akan tetapi setelah diberikan arahan, peserta didik akhirnya dapat menjawab dengan tepat. Secara keseluruhan, peserta didik dapat memahami operasi penjumlahan matriks dan sifat-sifatnya dengan baik.

Berbeda dengan pertemuanpertemuan sebelumnya, pada pertemuan 4 peserta didik dapat mengerjakan LKPD dengan baik tanpa bertanya kepada guru. Peserta didik tidak mengalami kesulitn dalam mengerjakan LKPD. Peserta didik juga lebih bersemangat seperti pertemuan 3 . Secara keseluruhan, peserta didik dapat memahami operasi pengurangan matriks dan sifat-sifatnya dengan baik.

Pada pertemuan 5, kegiatan pembelajaran dapat terlaksana dengan baik, tetapi peserta didik sering mengalami kesulitan pada kegiatan generalization terkait perkalian skalar pada matriks dan perkalian dua matriks. Selain itu, peserta didik juga mengalami kesulitan dan bahkan melakukan 
kesalahan ketika mengalikan matriks A dan matriks B pada aktivitas 4 . Hal ini disebabkan karena ordo matriks yang akan dikalikan berbeda dengan contoh yang diberikn. Oleh karena itu, peserta didik sering bertanya kepada guru. Hasil angket uji praktikalitas disajikan pada Tabel 5.

Tabel 2. Hasil angket uji praktikalitas

\begin{tabular}{lcc}
\hline \multicolumn{1}{c}{ Aspek } & $\begin{array}{c}\text { Praktika } \\
\text { litas }\end{array}$ & \multicolumn{1}{c}{ Kategori } \\
\hline $\begin{array}{l}\text { Kemudahan } \\
\text { Penggunaan }\end{array}$ & 87,50 & Sangat Praktis \\
$\begin{array}{l}\text { Efisiensi } \\
\text { Waktu }\end{array}$ & 91,67 & Sangat Praktis \\
$\begin{array}{l}\text { Daya Tarik } \\
\text { Kemudahan }\end{array}$ & 87,50 & $\begin{array}{l}\text { Sangat Praktis } \\
\text { Dipahami }\end{array}$ \\
$\begin{array}{l}\text { Manfaat } \\
\text { LKPD }\end{array}$ & 90,42 & Sangat Praktis \\
\hline \multicolumn{1}{c}{ Rata - Rata } & $\mathbf{8 8 , 4 7}$ & Sangat Praktis \\
\hline
\end{tabular}

Berdasarkan Tabel 2 diperoleh kesimpulan bahwa rata-rata nilai praktikalitas LKPD sebesar 88,47 dengan kategori sangat praktis. Hal ini menunjukkan bahwa LKPD dapat dengan mudah digunakan oleh peserta didik saat pembelajaran di sekolah.

Wawancara dengan peserta didik dilakukan setelah kelompok kecil. Kesimpulan yang diperoleh adalah peserta didik dapat dengan mudah menggunakan LKPD karena petunjukpetunjuk yang diberikan sudah lengkap dan jelas. Peserta didik juga merasa terbantu dalam memahami materi pembelajaran karena materi yang disajikan dikaitkan dengan permasalahan yang dekat dengan kehidupan mereka. Selain itu, tulisan pada LKPD juga jelas dan dapat dibaca serta bahasanya juga mudah dipahami. Kemudian, dari segi tampilan LKPD, peserta didik menyukai tampilan baik halaman sampul maupun isi LKPD yang memiliki gambar dan warna yang bervariasi. Oleh karena itu, peserta didik juga senang dan antusias dalam belajar menggunakan LKPD. Dari segi waktu, peserta didik mengatakan bahwa alokasi waktu cukup efisien dalam mengerjakan LKPD dan melaksanakan kegiatan pembelajaran.

\section{B. Pembahasan}

LKPD divalidasi oleh para ahli berdasarkan aspek-aspek validitas. Setelah divalidasi oleh ahli, diperoleh LKPD berbasis discovery learning yang telah valid untuk semua aspek penilaian. Rata-rata nilai validitas LKPD berbasis discovery learning adalah $82,78 \%$ dengan kategori sangat valid. Berdasarkan hasil yang diperoleh tersebut, maka dapat disimpulkan bahwa LKPD berbasis discovery learning telah valid dan layak digunakan untuk pembelajaran matematika.

Kegiatan belajar yang dilakukan oleh peserta didik pada LKPD sesuai dengan langkah-langkah model discovery learning. LKPD ini disajikan dalam beberapa aktivitas yang dikerjakan peserta didik secara berkelompok. Dengan demikian, peserta didik dituntut agar dapat berkolaborasi serta aktif dalam kelompoknya.

LKPD menyajikan masalah kontekstual atau masalah kehidupan sehari-hari yang dapat menimbulkan kebingungan peserta didik sehingga merangsang keingintahuan peserta didik untuk menyelesaikan masalah tersebut. Setelah itu, peserta didik dituntut untuk menyelesaikan masalah tersebut agar peserta didik mampu menemukan konsep atau prinsip.

LKPD juga menyajikan materi secara sistematis. Materi pada LKPD mengacu pada kurikulum 2013. Isi LKPD disesuaikan dengan karakteristik dan kebutuhan peserta didik. Selain itu, bahasa pada LKPD menggunakan 
Bahasa Indonesia yang sederhana dan mudah dipahami serta sesuai dengan kaidah ejaan bahasa indonesia (EBI). LKPD juga disajikan dengan jenis dan ukuran tulisan yang jelas serta mudah dibaca. Desain tampilan LKPD baik cover maupun isi juga menarik dari segi tata letak, huruf, warna, dan gambar.

Praktikalitas LKPD merujuk pada kemudahan yang didapatkan ketika menggunakan LKPD tersebut. Untuk mengetahui praktikalitas LKPD telah dilakukan penyebaran angket uji praktikalitas kepada peserta didik. Berdasarkan hasil angket uji praktikalitas, diperoleh bahwa nilai praktikalitas LKPD untuk masingmasing aspek penilaian sudah memenuhi kategori praktis. Rata-rata nilai praktikalitas LKPD berbasis discovery learning adalah $88,47 \%$ dengan kategori sangat praktis.

Secara keseluruhan, pembelajaran pada setiap pertemuan dapat dilaksanakan dengan baik serta pelaksanannya sesuai RPP yang telah dirancang walaupun masih ada arahan dari guru. Selain itu, alokasi waktu yang diberikan juga efisien untuk mengerjakan kegiatan-kegiatan pada LKPD. Peserta didik dapat memahami materi pada setiap pertemuan LKPD. Peserta didik dapat menjawab pertanyaan pada LKPD dengan baik serta mengerjakan perintah pada LKPD dengan baik. Peserta didik juga tertarik dan bersemangat untuk belajar dengan menggunakan LKPD.

Berdasarkan hasil angket uji praktikalitas, diperoleh kesimpulan bahwa dari segi aspek kemudahan penggunaan, peserta didik memperoleh kemudahan dari LKPD berbasis discovery learning. Hal ini disebabkan karena petunjuk pada LKPD jelas dan mudah dipahami serta ukuran huruf jelas dan dapat dibaca. Kemudian, dari segi waktu, alokasi waktu yang disediakan cukup efisien. Dari segi daya tarik, kombinasi warna menarik dan penyajian LKPD membuat peserta didik menjadi bersemangat dalam mengikuti pembelajaran dengan menggunakan LKPD tersebut. Dari segi kemudahan untuk dipahami, bahasa, perintah, maupun pertanyaan pada LKPD jelas dan mudah dipahami. Selain itu, dari segi manfaat LKPD, peserta didik merasa terbantu dalam memahami materi pembelajaran dengan baik. Kegiatan pada LKPD juga dapat membiasakan peserta didik dalam berpikir untuk menemukan konsep atau prinsip sehingga dapat mengkonstruksi pengetahuannya. Dengan begitu, dapat dikatakan bahwa LKPD berbasis discovery learning memperoleh respon positif dari peserta didik.

Penelitian terdahulu yang dilakukan oleh Suhendri (Suhendri et al., 2018) menyatakan bahwa LKPD berbasis discovery learning juga menperoleh respon positif dari peserta didik. Dengan menggunakan LKPD berbasis discovery learning, peserta didik menjadi terbantu dalam memahami konsep atau prinsip. Selain itu, LKPD juga membantu peserta didik untuk memecahkan masalah, bernalar, dan menarik kesimpulan.

Lebih lanjut, dalam penelitian lain disebutkan bahwa LKPD berbasis discovery learning memperoleh respon positif (Kariman et al., 2019) dan (Fadli \& Mirna, 2019). Peserta didik merasa senang dengan kegiatan yang disajikan pada LKPD berbasis discovery learning. Petunjuk atau arahan pada LKPD membuat peserta didik aktif dan saling berinteraksi sehingga terbantu dalam menyelesaikan masalah.

Penelitian ini memberikan kontribusi terhadap pembelajaran topik matriks. Dengan bantuan LKPD ini 
peserta didik dapat dipandu dalam menemukan suatu konsep matrik. Jadi pembelajaran dengan menggunakan LKPD ini dapat membantu peserta didik dalam memahami berbagai konsep dan prinsip yang ada.

\section{KESIMPULAN DAN SARAN}

Berdasarkan hasil penelitian yang telah dilakukan, diperoleh kesimpulan, yaitu 1) LKPD berbasis discovery learning sudah valid dari segi aspek penyajian, kelayakan isi, kebahasaan, dan kegrafikaan, 2) LKPD berbasis discovery learning sudah praktis dari segi aspek kemudahan penggunaan, efisiensi waktu, daya tarik, kemudahan untuk dipahami, dan manfaat LKPD.

Berdasarkan penelitian ini disarankan agar peneliti lain dapat mengujicobakan LKPD pada kelas besar untuk melihat efektifitasnya.

\section{DAFTAR PUSTAKA}

Andriyani, R., \& Saputra, N. N. (2020). Optimalisasi Kemampuan Higher Order Thinking Skills Mahasiswa Semester Awal melalui Penggunaan Bahan Ajar Berbasis Berpikir Kritis. Al-Khwarizmi: Jurnal Pendidikan Matematika dan Ilmu Pengetahuan Alam, 8(1), 77-86.

Apertha, F. K. P., Zulkardi., \& Yusup, M. (2018). Pengembangan LKPD Berbasis Open Ended Problem pada Materi Segiempat Kelas VII. Jurnal Pendidikan Matematika, 12(2), 4762.

Arifin, N., \& Abadi, A. M. (2018). Pengembangan Perangkat Pembelajaran Matematika dengan Discovery Learning Berorientasikan Kemampuan Penalaran dan Komunikasi Matematis. Jurnal Pendas Mahakam, 3(2), 125-138.

Fadli, M., \& Mirna. (2019). Pengaruh Penerapan Model Discovery Learning Terhadap Kemampuan
Penalaran Matematis Peserta Didik di Kelas VIII SMPN 8 Padang. Jurnal Edukasi dan Penelitian Matematika, 8(3), 137-142.

Fitriyana, N., \& Purwasi, L. A. (2020). Pengembangan Lembar Kerja Siswa Berbasis Discovery Learning. Jurnal Pendidikan Matematika: Judika Education, 3(1), 17-25.

Haeruman, L. D., Rahayu, W., \& Ambarwati, L. (2017). Pengaruh Model Discovery Learning Terhadap Peningkatan Kemampuan Berpikir Kritis Matematis dan Self-confidence Ditinjau dari Kemampuan Awal Matematis Siswa SMA di Bogor Timur. Jurnal Penelitian dan Pembelajaran Matematika, 10(2), 157-168.

Hakim, L., \& Noer, S. H. (2021). Penggunaan Multimedia Berbantuan Teknologi Informasi dan Komunikasi Berbasis Metode Penemuan Terbimbing. AKSIOMA: Jurnal Program Studi Pendidikan Matematika, 10(2), 1234-1241.

Hendri, S., \& Kenedi, A. K. (2018). Pengembangan Perangkat Pembelajaran Matematika Berbasis Discovery Learning Untuk Meningkatkan Kemampuan Pemecahan Masalah Siswa Kelas VIII SMP. Jurnal Inspirasi Pendidikan, 8(2), 10-24.

Irwan, Asmar, A., \& Syarifuddin, H. (2018). The Development of Mathematical Learning Material Based on Model-Eliciting Activities (MEAs) Approach to Improve Mathematical Problem Solving Skill of Students of Grade X of Senior High School Padang. Journal of Physics: Conference Series, 1040(1), $1-8$.

Kariman, D., Harisman, Y., Sovia, A., \& Prahmana, R. C. I. (2019). Effectiveness of Guided DiscoveryBased Module: A Case Study in Padang City, Indonesia. Journal on 
DOI: https://doi.org/10.24127/ajpm.v10i4.4193

Mathematics Education, 10(2), 239250.

Kemendikbud. (2016). Peraturan Menteri Pendidikan dan Kebudayaan Nomor 22 Tahun 20116 Tentang Standar Proses Pendidikan Dasar dan Menengah. Jakarta: Kemendikbud.

Meiliputri, R. I., Syarifuddin, H., Musdi, E., \& Asmar, A. (2021). Pengembangan Perangkat Pembelajaran Matematika Berbasis Discovery Learning Untuk Meningkatkan Kemampuan Pemecahan Masalah Siswa Kelas VIII SMP/MTs. Jurnal Edukasi Matematika dan Sains, 9(2), 417423.

Noprinda, C. T., \& Soleh, S. M. (2019). Pengembangan Lembar Kerja Peserta Didik (LKPD) Berbasis Higher Order Thinking Skill (HOTS). Indonesian Journal of Science and Mathematics Education, 2(2), 168176.

Nurhikmayati, I., \& Jatisunda, M. G. (2019). Pengembangan Bahan Ajar Matematika Berbasis Scientific yang Berorientasi pada Kemampuan Berpikir Kritis Matematis Siswa. Mosharafa: Jurnal Pendidikan Matematika, 8(1), 49-60.

Pansa, H. E., Caswita., \& Suharsono. (2017). Pengembangan LKPD dengan Model Problem Based Learning untuk Meningkatkan Kemampuan Komunikasi Matematis Siswa. Jurnal Pendidikan Matematika Universitas Lampung, 5(3), 1-12.

Plomp, T., \& Nieveen, N. (2013). Educational Design Research Part A: An Introduction. Enschede: Netherlands Institute for Curriculum Development (SLO).

Romadon, S., \& Mahmudi, A. (2019). Penerapan Pendekatan Penemuan Terbimbing Untuk Meningkatkan Kemampuan Pemahaman Konsep Matematis Siswa. AKSIOMA: Jurnal Program Studi Pendidikan
Matematika, 8(1), 58-64.

Rosmaiyadi. (2017). Analisis Kemampuan Berpikir Kritis Matematis Siswa dalam Learning Cycle 7E Berdasarkan Gaya Belajar. AKSIOMA: Jurnal Program Studi Pendidikan Matematika, 6(1), 12-19. Septian, R., Irianto, S., \& Andriani, A. (2019). Pengembangan Lembar Kerja Peserta Didik (LKPD) Matematika Berbasis Model Realistic Mathematics Education. Jurnal Educatio FKIP UNMA, 5(1), 59-67.

Suhendri, Z., Yerizon., \& Ratnawulan. (2018). Development of Guided Discovery Learning Mathematics for Student's Reasoning Ability Class X SMA/MA. 2nd International Conference on Mathematics and Mathematics Education 2018 (ICM2E 2018), 285, 186-189.

Wijaya, E. Y., Sudjimat, D. A., \& Nyoto, A. (2016). Transformasi Pendidikan Abad 21 Sebagai Tuntutan Pengembangan Sumber Daya Manusia di Era Digital. Prosiding Seminar Nasional Pendidikan Matematika, 1, 263-278.

Yerizon, Putra, A. A., \& Subhan, M. (2018). Student Responses Toward Student Worksheets Based on Discovery Learning for Students with Intrapersonal and Interpersonal Intelligence. IOP Conference Series: Materials Science and Engineering, 335(1), 1-4.

Zulfah. (2017). Tahap Preliminary Research Pengembangan LKPD Berbasis PBL untuk Materi Matematika Semester 1 Kelas VIII SMP. Jurnal Cendekia: Jurnal Pendidikan Matematika, 1(2), 1-12. 